Elementary Applied Aerodynamics

By Prof. Paul E. Hemke. (Prentice-Hall Aeronautical Engineering Series.) Pp. viii+231. (New York : Prentice-Hall, Inc.; London : Constable and Co., Ltd., 1946.) 26s. not.

$\mathrm{T}$ HIS American volume is essentially a tutorial or class text-book of the type that has not yet made extensive appearance in the field of English aeronautical literature. It treats the subject in logically arranged chapters, each one ending with a number of examples. These are both of the kind that emphasizes the theory already explained, and those giving the technical application of the subject-matter of that chapter. References in these questions to the relevant parts in the discussions, by means of a decimal system of numbering the paragraphs and conclusions reached, make the whole book extremely easy to follow, in a tutorial sense. As an examination crammer it is splendid; whether it is advisable to spoon-feed a student to such an extent is another matter.

The reader will have to take a good deal of the data for granted, especially that given in many of the charts, as reference to the source of the information is not always given. This is, of course, inevitable in a book that attempts to compress the subject into so small a space. It also dates the book rather badly, as the inquiring reader will find it difficult to link up the subject-matter with more recent advances. Aerodynamics is treated in a series of chapters on units, physics of the air, the ideal fluid, viscosity, compressibility, the properties of airfoils, propellers, performance and the helicopter. The author states in his opening remarks that he has dealt with only "the consideration of the more well known and established facts in aerodynamics". The book obviously has been written with the outlook of the exercise class, and in this limited field it can be recommended.

\section{Mathematics of Statistics}

By John F. Kenney. Part 1. Second edition. Pp. xii+260. (New York: D. Van Nostrand Co., Inc.; London: Macmillan and Co., Ltd., 1947.) $21 s$. net.

7 HIS is the first volume of a second edition of a book first published in 1939. The complete book is intended to be an introduction to the more elementary theory and methods of mathematical statistics. The present volume confines its attention almost exclusively to the descriptive theory of statistics. Within this limit, it provides a very carefully and clearly written and admirably printed introduction to the subject, well suited to a student without mathematical knowledge, or working alone. After chapters on the description of frequency distribution by graphical methods, averages, moments and measures of dispersion, the normal distribution is shortly considered, followed by the fitting of linear and quadratic polynomials and the theory of correlation. These subjects are explained with great clarity and at considerable length; but it seems a pity that in so large a book, costing so much, no room was found for an elementary account of sampling and the testing of statistics. As a consequence the student who wishes to decide how much reliance to put on the results of his calculations will have to turn to volume 2 or some other book. This volume by itself is therefore not very useful to a biologist or other experimentalist.

P. A. Moran

\section{La lutte contre les termites}

Par Ch. Noriot et H. Alliot. (Publication de l'Office de la Recherche scientifique coloniale.) Pp. 96. (Paris : Masson et Cie., 1947.) 220 francs.

T'T may be said, at the outset, that this publication 1 provides the best short modern account of termites and their control. It is, furthermore, extremely well illustrated and admirably printed on very good paper. The first part deals with the general biology of termites and the outlines of their classification. Part 2 is devoted to the application of various methods for destroying these insects, and Part 3 describes in some detail, and with many structural diagrams, the best methods for protecting woodwork against termite attack, and the special features needed in building construction in guarding against their depredations. Each section is accompanied by a short but adequate list of references to the relevant literature that may be consulted. There is also a list of the various trees stated to be resistant to termite injury.

A. D. I.

\section{Honey Farming}

By R. O. B. Manley. Pp. $293+15$ plates. (London : Faber and Faber, Ltd., 1946.) 18s. net.

R. MANLEY, who is one of the very few people $1 \mathrm{I}$ in the British Isles who can claim to be a honey farmer and to maintain successfully a large number of colonies of bees, is a person whose opinion on all matters relating to bee-keeping is well worth hearing. His latest book, "Honey Farming", is a worthy successor to his earlier excellent and widely read work "Honey Production in the British Isles".

In this new book Mr. Manley draws upon his wealth of practical experience and, in an eminently readable manner, gives some of his ideas about bee-keeping and the methods of management that he is using to-day, relating not only something of his successes but also telling of his failures and how the methods that he is now employing were gradually developed. Needless to say, he thoroughly disagrees with many of the methods still taught and practised by some of the less well-informed bee-keepers, and he does not hesitate to say so, or to criticize severely some of the equipment still advocated for general use. Indeed this book, besides being of inestimable value to those people who wish to learn what a man who has been successful in earning a living from honey production thinks about various systems of management, apiary equipment, bee-breeding, swarm control, queen intro. duction, and much else besides, will also be a tonic to those who have wished for so long to see the archaic nonsense still talked about bee-keeping exposed.

This is indeed one of the few books about beekeeping that one can unreservedly recommend, and one that I hope will find a place in the library of every bee-keeper.

C. G. ButLER

\section{Dairy Farming}

Theory and Practice. By V. C. Fishwick. (Agricultural and Horticultural Series.) Pp. $237+55$ plates. (London: Crosby Lockwood and Son, Ltd., 1947.) 15s. net.

AEATURE of this book is that about half of it $A$ is devoted to concise descriptions of the methods and views of twenty dairy farmers. Six of these farmers are said to be men with a national reputation, seven are well known in their own locality and the 